\title{
Sosialisasi Pembayaran Iuran dan Monitoring SiWarga Berbasis Teknologi pada Perumahan Griya Pesona Asri Surabaya
}

\author{
Hariadi Yutanto ${ }^{1}$, Ellen Theresia Sihotang ${ }^{2}$, Putri Wulanditya ${ }^{3}$, Pepie Diptyana ${ }^{4}$ \\ ${ }^{1,3}$ Departemen Diploma 3 Akuntansi, ${ }^{2}$ Departemen Manajemen, ${ }^{4}$ Departemen Akuntansi \\ STIE Perbanas Surabaya, Jl. Nginden Semolo, No 34-36 Surabaya, 60118, Indonesia
}

\section{ARTICLE INFO:}

Received: 2020-05-02 Revised: 2020-06-14

Accepted: 2020-07-02

\section{Keywords:}

Electornic Application

SiWarga GPA;

Financial System;

Cashless Payment;

Integrated System

\begin{abstract}
Griya Pesona Asri (GPA) is a residence which located in the northern part of Surabaya City. The specific location is in Medokan Ayu, Rungkut District. Since 2019, this residence has been used SiWarga electronic application to improve citizen administration. In the beginning 2020, the leader of RT 04 RW 10, designed an electronic citizen financial system as the development of SiWarga GPA that has been successfully used for data collection of local residents. Some of partner problems are financial management transparently; noncash payment system to facilitate citizen's fee transactions; reduce citizens risk overdue arrears. In relation with these partner problems, some activities that have been carried out begins with discussion housing residents and management, followed by the management and development of non-cash payment system features until socialization the operating system. A number of RT managers have mastered to use several, they have been quite proficient and enthusiastic. The residents have been able to monitor a number of arrears in payment. Administrators of RT no longer need to collect money. The administrators have also been able to know the total expenditure and income so that it can be used for the cash budgeting.
\end{abstract}

(C) 2020 Published by University of Merdeka Malang. This is an open access article distributed under the CC BY-SA 4.0 license

(https://creativecommons.org/licenses/by-sa/4.0/)

How to cite: Yutanto, H., Sihotang, E. T., Wulanditya, P., \& Diptyana, P. (2020). Sosialisasi Pembayaran luran dan Monitoring SiWarga Berbasis Teknologi pada Perumahan Griya Pesona Asri Surabaya. Abdimas: Jurnal Pengabdian Masyarakat Universitas Merdeka Malang, 5(2), 168-179. https://doi.org/10.26905/abdimas.v5i2.4347

\section{PENDAHULUAN}

Perkembangan teknologi informasi yang cukup pesat membuat perilaku manusia juga berubah untuk dapat beradaptasi. Tidak hanya pada sektor bisnis, pemanfaatan teknologi informasi juga dikembangkan dalam kehidupan bermasyarakat. Manfaat teknologi informasi secara konsep dapat meningkatkan kinerja individu maupun organisasi. Selain itu juga memberikan kemudahan, yang diyakini dapat memberikan efisiensi proses dan waktu, sehingga segala sesuatu dapat dilakukan dengan segera tanpa harus menunggu 
dalam waktu yang lama (Davis, 1989). Inovasi teknologi informasi dan komunikasi telah mempengaruhi perilaku warga negara, kebutuhan informasi mereka, dan cara orang bekerja dan berkomunikasi. Kemajuan ini memengaruhi struktur sosial, budaya, komersial, dan publik. Internet, khususnya, telah mengintensifkan transformasi digital, karena itu membawa kemampuan untuk mengakses berbagai informasi, cara-cara interaksi baru dan juga mendukung penciptaan dan berbagi pengetahuan (Gasova \& Stofkova, 2017). Kehadiran teknologi juga dimanfaatkan oleh sektor pemerintahan, dengan menghadirkan sistem pemerintahan elektronik (electronic government/e-government). Strategi layanan pemerintahan yang berbasis elektronik tersebut diarahkan pada penyelesaian yang bersifat transparan. Interaktivitas sebagai faktor penting yang secara langsung mempengaruhi kepuasan e-government dan secara tidak langsung mempengaruhi kepercayaan. Layanan pemerintah berbasis situs web dihadirkan dalam rangka memenuhi kebutuhan individu yang memang memerlukan layanan tersebut dan pada akhirnya menuntut sekelompok individu atau warga untuk menggunakannya (Welch, Hinnant, \& Moon, 2005). Seiring dengan perkembangan teknologi yang cepat, pola dan sistem pembayaran dalam transaksi ekonomi terus berubah. Kemajuan teknologi dalam instrumen pembayaran menggeser peran uang tunai sebagai alat pembayaran dalam bentuk pembayaran non tunai yang lebih efisien dan ekonomis (Lintangsari et al., 2018). Konsepnya adalah transformasi sistem manual ke sistem berbasis elektronik. Namun, tidak semua proses kerja dapat ditrasformasi dalam bentuk elektronik. Beberapa diantaranya ada yang masih diproses secara manual. Meskipun demikian, sistem elektronik tersebut telah mempersingkat proses kerja pemerintahan dan yang terpenting lagi adanya manajemen data dasar (database) kependudukan yang lebih rapi, sehingga informasi yang dihasilkan menjadi lebih cepat, akurat, lengkap dan tentu saja efisiensi pada biaya pengelolaan data dan pencarian informasi.

Mengadopsi konsep e-government tersebut, Perumahan Griya Pesona Asri (GPA) RT 04, RW 10, Kelurahan Medokan Ayu, Kecamatan Rungkut, Surabaya berlokasi di wilayah utara kota Surabaya (Gambar 1). Perumahan yang berjarak $1 \mathrm{~km}$ dari wisata hutan mangrove, telah menciptakan tata ruang yang nyaman dan aman dengan menjuarai Surabaya Green \& Clean, 2017. Sistem keamanan perumahan juga dilengkapi dengan Closed Circuit Television (CCTV) yang dipasang pada setiap titik rawan dan dapat dimonitoring oleh warga setiap waktu. Denah lokasi pelaksanaan Program Kemitraan Masyarakat ini tercantum pada Gambar 2.
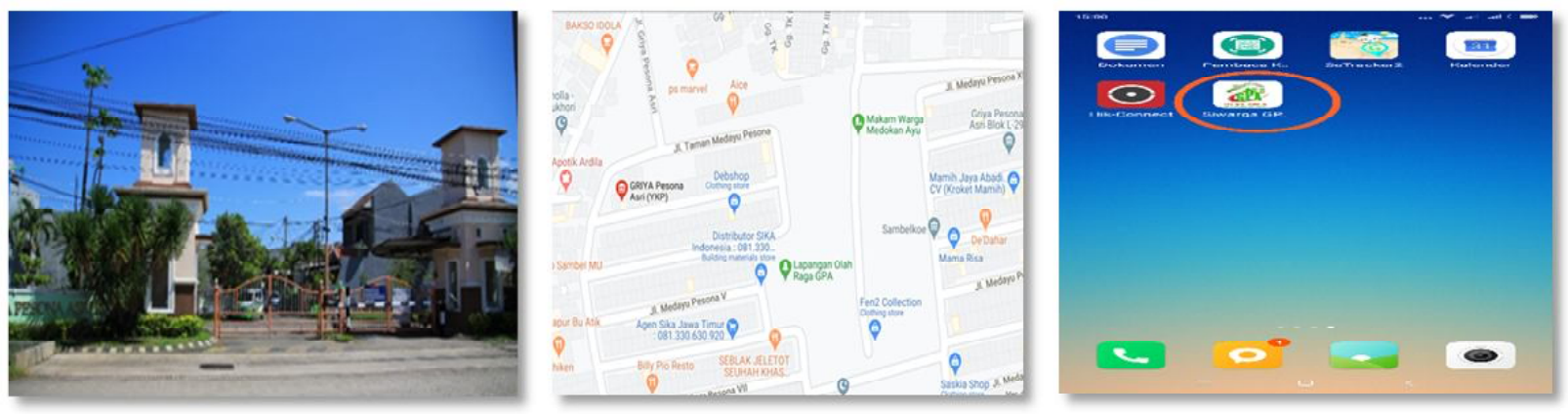

Gambar 1. Perumahan Griya Pesona Asri Gambar 2. Denah Lokasi Perumahan Griya Pesona Asri

Gambar 3. Aplikasi SiWarga 


\section{ABDIMAS: Jurnal Pengabdian Masyarakat Universitas Merdeka Malang}

Volume 5, No 2, Juli 2020: 168-179

Perumahan Griya Pesona Asri sejak tahun 2019 telah menggunakan aplikasi berbasis web yang dapat diakses kapan dan dimana saja, tanpa harus menginstal aplikasi desktop dengan menggunakan koneksi internet (Gasova \& Stofkova, 2017), nama dari aplikasi tersebut adalah SiWarga GPA. Akses SiWarga GPA menggunakan teknologi internet dibagi menjadi dua laman, meliputi akses oleh warga sendiri dan pengurus. Login oleh pengurus sebagai administrator/pengurus RT dapat diakses melalui laman http:// gpaykp.info/login sedangkan akses oleh warga melalui http://siwarga.gpaykp.info/. Menu yang sudah tercantum pada aplikasi web, meliputi profil perumahan, berita, gallery, kontak beserta info warga (Yutanto et al., 2019). Aplikasi tersebut merupakan hasil dari penelitian internal yang dipelopori oleh Hariadi Yutanto selaku dosen Diploma 3 Akuntansi STIE Perbanas Surabaya.

Pada Gambar 3 merupakan perkembangannya aplikasi tersebut saat ini telah berbasis Android. Aplikasi tersebut juga telah berhasil mengelola data dasar (database) warga perumahan terkait administrasi warga yang datang maupun yang keluar. Bahkan telah digunakan untuk pemungutan suara (e-voting) pada pemilihan ketua RT/RW. Kehadiran SiWarga GPA telah mengubah perilaku warga untuk berkomitmen pada penggunaan teknologi dan telah mendapatkan pengakuan dari Pemerintah Kota Surabaya dengan menjadi juara 1 pada kegiatan Surabaya Digital City pada 19 Januari 2020.

Dampak dari penggunaan SiWarga pada perkembangannya juga masih belum dapat mengatasi beberapa permasalahan yang secara khusus terkait dengan pengelolaan keuangan warga. Beberapa pengurus warga khususnya ketua RT 04, menyampaikan beberapa kendala yang terkait dengan keuangan warga, sebagai berikut.

Perumahan GPA saat ini telah memiliki 180 kepala keluarga. Pencatatan iuran warga melalui formulir iuran masih secara manual. Warga harus membawa formulir iuran yang diberikan kepada bendahara RT/ pengurus keuangan warga. Selanjutnya dilakukan verifikasi tanda tangan dan distempel.

Sistem pembayaran iuran warga masih dilakukan secara tunai. Pengurus warga masih melakukan penagihan ke sejumlah rumah warga (door to door). Namun, ketika ditagih terkadang sejumlah warga tidak ada di rumah, karena yang bersangkutan bekerja, sehingga proses penagihan tertunda kembali dan terjadi tunggakan serta tidak efisien dari waktu bagi pihak pengurus.

Sejumlah warga juga menginginkan adanya pelaporan keuangan warga secara rutin berkaitan dengan pemasukan dan pengeluaran kas sehingga ada transparansi melalui pelaporan rutin.

Ketiga hal tersebut menjadi permasalahan mendasar bagi sejumlah warga pada perumahan GPA, setelah menggunakan SiWarga. Berdasarkan permasalahan tersebut, maka perlu dilakukan pengembangan lebih lanjut pada aplikasi SiWarga.

Tujuan utama dari kegiatan pengabdian yang dilakukan adalah memberikan solusi penyelesaian terhadap ketiga permasalahan tersebut. Tujuan yang lainnya adalah mengembangkan aplikasi SiWarga dengan menambahkan fitur terkait iuran dan laporan keuangan, karena warga perumahan telah merasakan efisiensi dan keefektifan penggunaan SiWarga GPA. Terutama, sejumlah pengurus warga yang sangat menyadari bahwa perlu adanya pengelolaan sistem keuangan warga berbasis elektronik. Manfaat dari pelaksanaan program kemitraan masyarakat ini adalah adanya pengembangan sistem informasi keuangan warga berbasis elektronik dan transparan dalam bentuk laporan rutin.

Identifikasi beberapa permasalahan mitra yang menjadi kebutuhan bagi warga perum Griya Pesona Asri RT 04, RW 10 sebagai berikut: (1) transparansi terhadap pengelolaan atau pelaporan keuangan iuran 
warga; (2) sistem pembayaran non tunai untuk mempermudah transaksi iuran warga; dan (3) mengurangi keterlambatan pembayaran maupun tunggkan iuran warga

Pengembangan aplikasi SiWarga yang terkait dengan pembayaran iuran non tunai sejalan dengan Peraturan Presiden (Perpres) No.82/206, tentang Strategi Nasional Keuangan Inklusif. Penciptaan keuangan inklusif salah satunya dapat dilakukan dengan menghadirkan sistem pembayaran non tunai (cashless) melalui media elektronik.

Beberapa solusi yang diajukan kepada mitra sebagai penyelesaian permasalahan adalah sebagai berikut: (1) pembenahan sistem pembayaran tunai menjadi non tunai berdasarkan data dasar (database) warga dengan mengatur kembali format kartu iuran warga menjadi online. (2) Pengaturan (set-up) keuangan kas RT, mengembangkan SiWarga GPA yang berbasis cloud computing untuk mencatat setiap penerimaan dan pengeluaran setiap bulannya. (3) Pendampingan pembaruan data dasar keuangan (up-date database) terhadap sejumlah pengurus RT terutama bendahara RT dengan melibatkan Remaja Karang Taruna Perum GPA sebagai media untuk pemutakhiran database warga dan set-up keuangan sebagai monitoring iuaran warga serta laporan keuangan RT. (4) Sosialisasi dan pendampingan sistem keuangan dengan SiWarga GPA di perumahan sebagai media pengenalan serta praktik integrasi database warga dengan sistem keuangannya. Integrasi ini bermanfaat bagi warga maupun pengurus. Warga akan semakin menyadari tanggungjawab pembayaran iuran serta memudahkan pengurus untuk memonitoring pembayaran, sehingga akan secara langsung dapat diinformasikan secara periodik kepada sejumlah warga yang masih memiliki tunggakan. (5) Pendampingan Mitra dalam batas waktu yang sudah disepakati baik dalam hal pembelajaran, pengoperasian, manajemen data, hingga inovasi. (6) Pemantauan pelaksanaan mitra sampai pada tahapan evaluasi keberhasilan mitra mengoperasikan sistem keuangan melalui SiWarga, khususnya yang terkait dengan laporan keuangan bulanan.

Tabel 1. Permasalahan, Target, Kegiatan, dan Luaran

\begin{tabular}{|c|c|c|c|c|}
\hline Aspek & Permasalahan & Target Kegiatan & Rencana Kegiatan & Luaran \\
\hline Manajemen & $\begin{array}{l}\text { - Kendala kartu } \\
\text { iuran warga } \\
\text { masih bersifat } \\
\text { manual } \\
\text { - Kendala } \\
\text { Pembayaran iuran } \\
\text { warga secara } \\
\text { tunai. }\end{array}$ & $\begin{array}{l}\text { - Merancang kartu } \\
\text { iuran/formulir iuran } \\
\text { secara elektronik } \\
\text { - Warga GPA RT } 04 \\
\text { memiliki kemampuan } \\
\text { membayar iuran } \\
\text { secara non tunai } \\
\text { melalui SiWarga }\end{array}$ & $\begin{array}{l}\text { - Diskusi dengan } \\
\text { warga GPA RT } 04 \\
\text { - Pendampingan } \\
\text { pembenahan } \\
\text { kartu pembayaran } \\
\text { iuran warga }\end{array}$ & $\begin{array}{l}\text { Peningkatan } \\
\text { pengetahuan dan } \\
\text { kemampuan dalam } \\
\text { melakukan } \\
\text { pembayaran secara } \\
\text { non tunai }\end{array}$ \\
\hline $\begin{array}{l}\text { Sistem } \\
\text { Informasi }\end{array}$ & $\begin{array}{l}\text { Kendala } \\
\text { pengelolaan Kas RT }\end{array}$ & $\begin{array}{l}\text { - Pembuatan Sistem } \\
\text { Informasi integrasi } \\
\text { Database warga dan } \\
\text { Kas RT } \\
\text { - Warga GPA RT } 04 \\
\text { memiliki kemampuan } \\
\text { mengoperasikan dan } \\
\text { memonitoring iuaran } \\
\text { beserta laporan Kas } \\
\text { RT pada sistem } \\
\text { informasi }\end{array}$ & $\begin{array}{l}\text { - Pembuatan } \\
\text { Sistem Keuangan } \\
\text { SiWarga GPA } \\
\text { - Pendampingan } \\
\text { Update Database } \\
\text { - Pendampingan } \\
\text { Sistem Keuangan } \\
\text { SiWarga GPA } \\
\text { - Pendampingan } \\
\text { pengoperasian } \\
\text { sistem dan e- } \\
\text { commerce }\end{array}$ & $\begin{array}{l}\text { - Pengembangan } \\
\text { sistem keuangan } \\
\text { pada sistem } \\
\text { SiWarga GPA } \\
\text { - Peningkatan } \\
\text { kemampuan } \\
\text { menggunakan } \\
\text { sistem informasi } \\
\text { dan e-commerce }\end{array}$ \\
\hline
\end{tabular}




\section{ABDIMAS: Jurnal Pengabdian Masyarakat Universitas Merdeka Malang}

Volume 5, No 2, Juli 2020: 168-179

\section{METODE}

Program Kemitraan Masyarakat ini dilaksanakan di Perumahan Griya Pesona Asri, RT 04, RW 10, Kelurahan Medokan Ayu, Kecamatan Rungkut, Kota Surabaya, Jawa Timur. Pelaksanaan program kemitraan berlangsung selama 6 bulan, terhitung dari Januari sampai dengan Juni 2020. Pelaksanaan kegiatan program kemitraan ini bertepatan dengan kondisi pandemi COVID-19 sehingga serangkaian kegiatan dilakukan secara daring dan ada beberapa yang dilaksanakan secara langsung dengan memperhatikan protokol menghadapi masa pandemi, seperti menjaga jarak, mencuci tangan dan menggunakan masker. Metode pelaksanaan meliputi metode kegiatan dan rancangan evaluasi.

Beberapa tahapan yang dilaksanakan pada kegiatan Program Kemitraan Masyarakat sebagai bagian dari metode pelaksanaan kegiatan adalah sebagai berikut:

\section{Tahap Persiapan}

Tahapan persiapan meliputi kegiatan: (1) koordinasi awal dengan sejumlah perangkat warga yang dihadiri oleh Ketua dan Wakil Ketua serta sejumlah Pengurus RT 04 RW 10. Agenda koordinasi berkaitan dengan kebutuhan dan keinginan warga terhadap pengembangan SiWarga terkait dengan fitur pembayaran iuran beserta pelaporannya. Termasuk mengumpulkan data iuran warga yang telah diterima maupun yang belum diterima oleh pihak pengurus warga. (2) Merancang pembaruan kartu iuran warga.

\section{Tahap Pelaksanaan Kegiatan}

Tahapan pelaksanaan kegiatan meliputi pembenahan database iuran warga dan pengelolaan keuangan kas RT, sebagai prioritas utama untuk mengelola database dengan melakukan pendataan ulang semua warga yang telah/belum mengumpulkan formulir iuran warga. Hasil dari pengumpulan data dan penyusunan kebutuhan sebagai dasar merancang kartu iuran elektronik dan terintegrasi dengan aplikasi SiWarga (Asana, Putra, \& Atmajaya, 2020).

Pengembangan Sistem Keuangan pada aplikasi SiWarga GPA Online sebagai media sistem informasi database warga dan keuangan RT. Sistem informasi berbentuk situs (website) yang telah dimiliki warga dengan portal masing-masing akan dilengkapi dengan sistem pembayaran iuran secara non tunai. Transformasi ini juga sejalan dengan Peraturan Presiden (Perpres) No.82/2016 tentang Strategi Nasional Keuangan Inklusif. Prosesnya ditempuh dengan menambahkan menu pembayaran iuran dan alur prosesnya pengacu pada Peraturan Bank Indonesia No.19/8/2017 tentang Gerbang Pembayaran Gateway dan Peraturan Bank Indonesia No.18/17/PBI/2016 perihal uang elektronik. Acuan tersebut menjadi panduan pengembangan sistem pembayaran SiWarga karena mempertimbangkan juga risiko keamanan. Selanjutnya, pengelolaan data dasar (database) keuangan pemasukan dan pengeluaran kas RT sampai kepada format pelaporannya.

Pendampingan update database keuangan kepada Pengurus RT dan Remaja Karang Taruna Perum GPA sebagai media untuk pemutakhiran database dan monitoring keuangan warga beserta laporan keuangan RT tiap bulannya.

Sosialisasi dan pendampingan SiWarga GPA sebagai media pengenalan serta praktik integrasi database warga dengan keuangannya yang bermanfaat pada pengelolaan keuangan terkait dengan 
monitoring iuran pada masing-masing warga. Beserta laporan keuangan yang disajikan dalam bentuk penerimaan dan pengeluaran kas setiap bulannya.

Pendampingan mitra dalam batas waktu yang sudah disepakati baik dalam hal pembelajaran, pengoperasian, manajemen data, e-commerce hingga inovasi.

Tabel 2. Tahapan dan indikator pencapaian

\begin{tabular}{ll}
\hline \multicolumn{1}{c}{ Tahapan } & \multicolumn{2}{c}{ Indikator capaian } \\
\hline - Membuat database yang diperlukan & - Database dalam bentuk softcopy. \\
iuran dan laporan keuangan dalam & - Adanya Fitur pembayaran iuran berupa penerimaan kas dan \\
aplikasi SiWarga & laporan kas RT pada aplikasi SiWarga \\
- Sinkronisasi data dengan menu baru & - Aplikasi Pembayaran Iuran SiWarga GPA. \\
- Pendampingan operasional & - Pengurus RT dapat melakukan set up, approve monitoring \\
& pembayaran warga. \\
& - Setiap warga perumahan dapat menggunakan aplikasi SiWarga \\
& GPA sebagai media pelaporan bukti pembayaran dan monitoring \\
& iuran bulanan. \\
- Mitra dapat melakukan update database dan monitoring iuran RT \\
- Monitoring evaluasi
\end{tabular}

\section{Metode Pendampingan}

Metode pendampingan yang dilaksanakan berkaitan dengan sejumlah kegiatan diantaranya: (1) Metode ceramah. Metode ceramah digunakan untuk memberikan penjelasan tentang pemanfaatan sistem keuangan melalui aplikasi online SiWarga GPA sebagai salah satu bagian dari pengembangan aplikasi tersebut. (2) Metode tanya jawab. Metode tanya jawab penting bagi para peserta pendampingan, baik pada saat menerima penjelasan tentang teori maupun pada saat mempraktekkan penggunaan SiWarga GPA. (3) Metode simulasi. Metode simulasi merupakan bagian dari uji coba SiWarga GPA yang terintegrasi dengan sistem keuangan warga. Metode ini menjadi penting untuk memberikan kesempatan mempraktekan materi pendampingan yang telah diperoleh

\section{Rancangan Evaluasi}

Keberhasilan dari pelaksanaan kegiatan ini menggunakan tiga indikator yang meliputi keberhasilan pada proses awal. Keberhasilan selama proses berlangsung dilakukan pada saat pendampingan dan proses akhir sebagai tahap penyelesaian dengan menilai tingkat kemanfaatan pelaksanaan kegiatan kemitraan masyarakat ini. (1) Indikator proses awal. Keberhasilan pelaksanaan kegiatan diukur dari terlaksananya sejumlah kegiatan pertemuan dengan warga maupun pengurus RT berdasarkan waktu yang telah ditentukan. (2) Indikator selama proses berlangsung. Kemampuan peserta mengoperasikan SiWarga GPA untuk pemutakhiran database warga yang mendukung pengelolaan keuangan RT pada saat pendampingan. Artinya ada peningkatan kemampuan dan keterampilan peserta terkait penggunaan sistem 
ABDIMAS: Jurnal Pengabdian Masyarakat Universitas Merdeka Malang Volume 5, No 2, Juli 2020: 168-179

informasi (Christanto, Handayani, \& Utomo, 2019) secara khusus pada fitur keuangan. Indikatornya adalah apabila lebih dari $90 \%$ peserta memahami kegiatan pendampingan, lebih dari $75 \%$ peserta mampu mempratekkan, dan lebih dari 50\% peserta bersedia mensosialisasikan kegiatan. Indikator proses akhir. Keberhasilan kegiatan pengabdian masyarakat pada proses akhir diukur dari beberapa hal sebagai berikut: (a) terselesaikannya fitur sistem keuangan sebagai pengembangan aplikasi SiWarga; (b) Kebermanfaatan kegiatan pendampingan dengan menggunakan instrumen yang tercantum pada Tabel 3; (c) Terlaksananya sosialisasi fitur iuran beserta laporan kepada segenap pengurus RT dan warga.

Tabel 3. Instrumen evaluasi kegiatan

\begin{tabular}{|c|c|c|c|c|c|c|}
\hline $\begin{array}{l}\text { Tingkat Pemanfaatan Pela } \\
\text { Pendampingan Sistem Keua }\end{array}$ & $\begin{array}{l}\text { sanaa } \\
\text { gan } \subseteq\end{array}$ & $\arg$ & & & & \\
\hline Petunjuk: Jawablah pernyataan berikut dengan memberi & Jawe & & & & & KET \\
\hline keadaan sebenarnya & 1 & 2 & 3 & 4 & 5 & \\
\hline Tingkat Pelaksanaan Pendampingan Kegiatan untuk Memah & & & & & & \\
\hline Pengetahuan tentang sistem keuangan SiWarga GPA & & & & & & \\
\hline $\begin{array}{l}\text { Mampu memahami penggunaan sistem keuangan SiWarga } \\
\text { GPA }\end{array}$ & & & & & & \\
\hline Mampu mengidentifikasi sistem keuangan SiWarga GPA & & & & & & \\
\hline Memahami manfaat sistem keuangan SiWarga GPA & & & & & & \\
\hline Merasakan manfaat sistem keuangan SiWarga GPA & & & & & & \\
\hline Tingkat Pelaksanaan Pendampingan Kegiatan untuk Mempr & ktekk & & me & & & \\
\hline $\begin{array}{l}\text { Mampu mengoperasikan sistem keuangan melalui SiWarga } \\
\text { GPA }\end{array}$ & & & & & & \\
\hline $\begin{array}{l}\text { Mampu mengaplikasikan sistem keuangan melalui SiWarga } \\
\text { GPA }\end{array}$ & & & & & & \\
\hline
\end{tabular}

\section{HASIL DAN PEMBAHASAN}

Pelaksanaan kegiatan kemitraan masyarakat ini berada pada tahapan kedua. Hasil yang diperoleh dari serangkaian tahapan tersebut adalah sebagai berikut: (1) Pengembangan kartu iuran warga yang masih manual berupa kertas menjadi digital. Kartu iuran menjadi fitur pada aplikasi SiWarga. (2) Pengembangan pembayaran iuran, pembukuan beserta pelaporannya menjadi fitur tambahan pada aplikasi SiWarga. Proses pengembangan fitur pembayaran terlebih dahulu dilakukan dengan menambahkan menu Master Kewajiban Warga pada laman Admin Page, yang peruntukannya hanya bagi pihak pengurus keuangan kas RT sebagai administrator. Master Data meliputi aktivitas penerimaan, pengeluaran dan pelaporan kas. Aplikasi ini memberikan fasilitas pengolahan data melalui inputan iuran yang menghasilkan laporan secara periodik (Kustriyanti, Windana, \& Shofiya, 2018) 

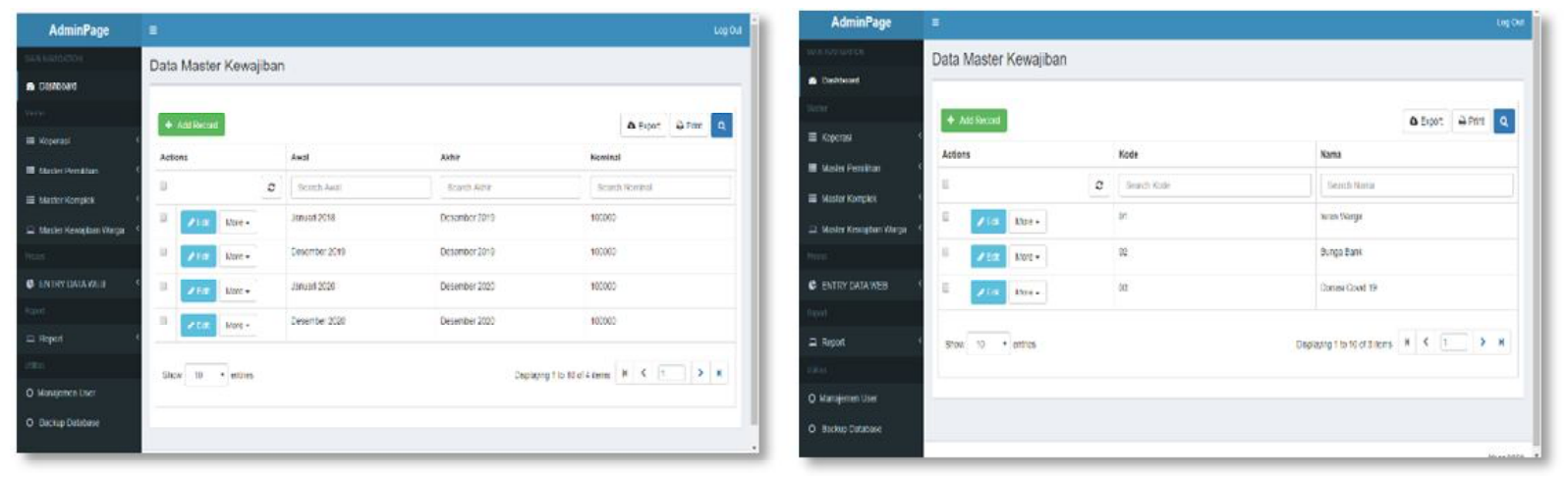

Gambar 4. Master Kewajiban Setup Kode Penerimaan Kas Gambar 5. Proses Generate Data Master

Selanjutnya data pada Master Kewajiban digunakan untuk proses generate tagihan berdasarkan kartu pembayaran digital dari masing-masing warga. Gambaran perihal proses generate iuran sejumlah warga tercantum pada Gambar 5 tentang Proses Generate Data Master.

Master pengeluaran berfungsi sebagai pengaturan (setup) kode setiap aktivitas pengeluaran kas RT. Pengeluaran kas RT meliputi iuran RW bulanan, iuran PKK bulanan, biaya internet CCTV, biaya pemeliharaan beserta biaya lain-lain. Selain, itu pengeluaran lainnya adalah berupa biaya administrasi bank yang dipotong secara langsung oleh pihak bank dan menjadi pembukuan kas RT. Gambar 6, merupakan master pengeluaran SiWarga.
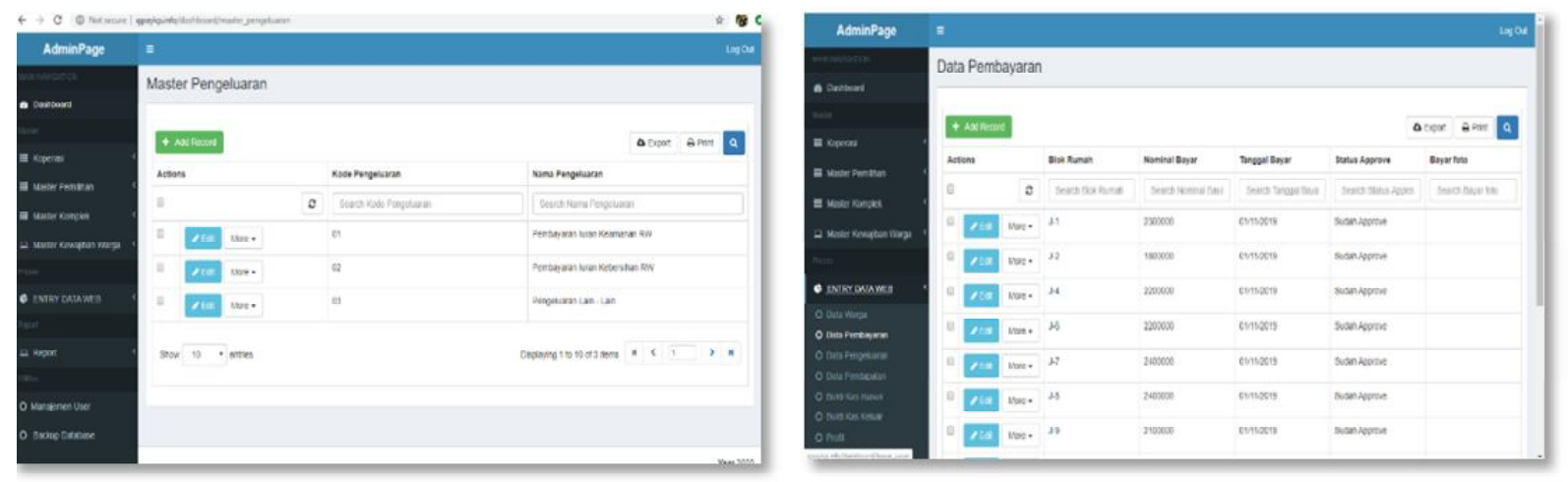

Gambar 6. Master Kewajiban Setup Kode Pengeluaran Kas

Gambar 7. Inputan Data Pembayaran

Membuat menu input data pada situs (entry data web). Setelah data master terbentuk, selanjutnya masih pada laman Admin Page ditambahkan Data Pembayaran yang digunakan oleh pengurus kas RT untuk validasi (approve) data pembayaran warga antara data yang di input (entry) oleh warga itu sendiri dengan notifikasi dari layanan elektronik bank (e-banking). Menu ini sekaligus memonitoring sejumlah warga yang sudah maupun belum membayar iuran wajib setiap bulannya. Bentuk dari menu tersebut tercantum pada Gambar 7 perihal inputan data pembayaran. 
ABDIMAS: Jurnal Pengabdian Masyarakat Universitas Merdeka Malang Volume 5, No 2, Juli 2020: 168-179

Selain inputan data pembayaran dilengkapi juga dengan data pengeluaran kas yang akan digunakan oleh pengurus untuk menginput sejumlah pengeluaran kas yang bersifat rutin maupun yang non rutin. Bentuk dari inputan data pengeluaran pada aplikasi SiWarga tercantum pada Gambar 8 perihal inputan data pengeluaran.
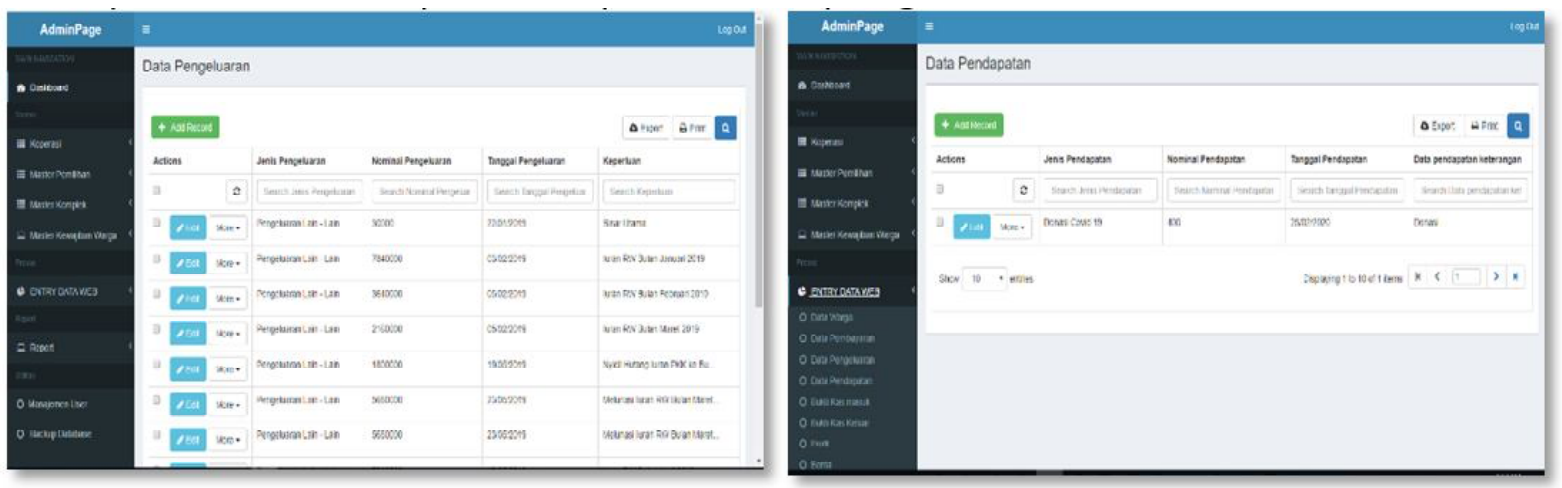

Gambar 8. Inputan Data Pengeluaran

Gambar 9. Inputan Data Pendapatan

Setelah data pengeluaran menu berikutnya adalah data pendapatan yang fungsinya untuk menginput sejumlah pendapatan kas selain iuran wajib warga. Bentuk inputan tersebut tercantum pada Gambar 9 tentang Inputan Data Pendapatan.

Membuat fitur Laporan Kas RT. Sejumlah inputan berupa pemasukan dan pengeluaran kas dapat dimonitoring oleh pengurus maupun warga melalui fitur Report Kas RT. Fitur tersebut terdiri dari report pemasukan, pengeluaran serta saldo pemasukan dan pengeluaran kas yang terakumulasi setiap bulan berjalan.

Membuat Report Pemasukan Kas. Fungsi dari fitur tersebut adalah untuk memonitor sejumlah pemasukan yang diterima secara rutin dari setiap warga beserta pendapatan yang sifatnya non rutin seperti penerimaan hibah atau bantuan pemerintah maupun sumbangan, selain itu juga berupa pendapatan bunga bank yang bersifat sebagai pendapatan lain-lain. Fitur report pemasukan kas tercantum pada Gambar 10 yaitu Report Pemasukan Kas.
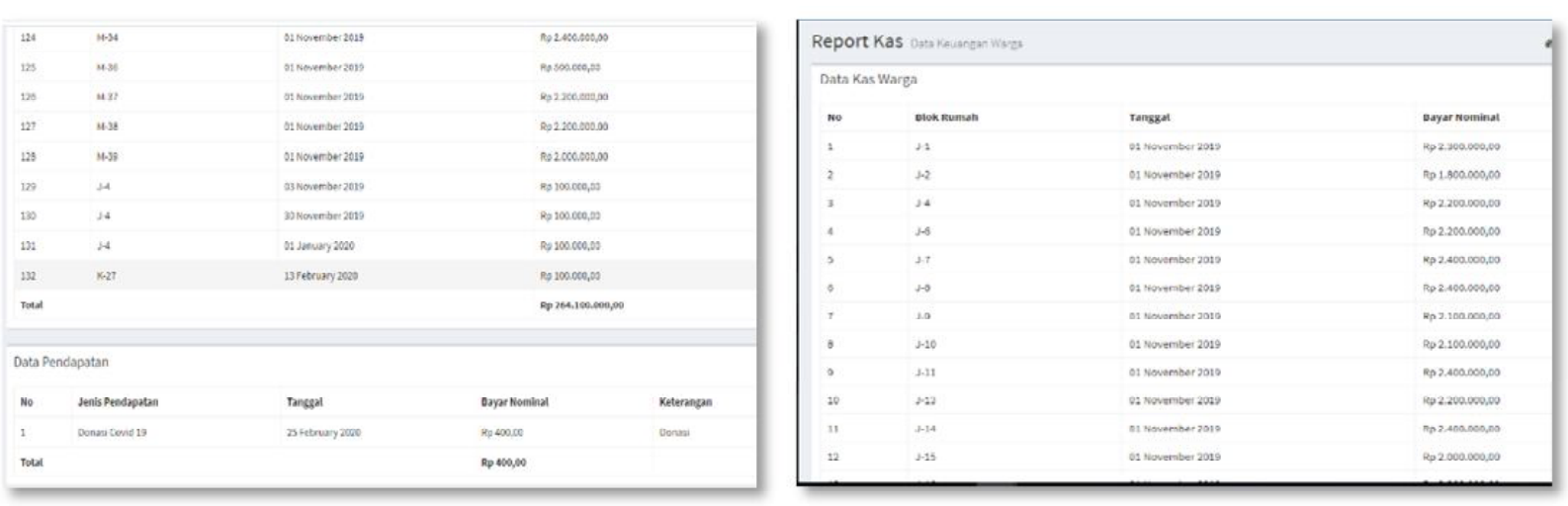

Gambar 10. Report Pemasukan Kas 
Membuat Report Pengeluaran Kas. Fitur ini dapat digunakan oleh pengurus RT untuk memonitoring sejumlah pengeluaran yang bersifat rutin maupun non rutin secara rinci berdasarkan urutan tanggal pengeluaran. Gambaran fitur ini tercantum pada gambar 11 yaitu Report Pengeluaran Kas.
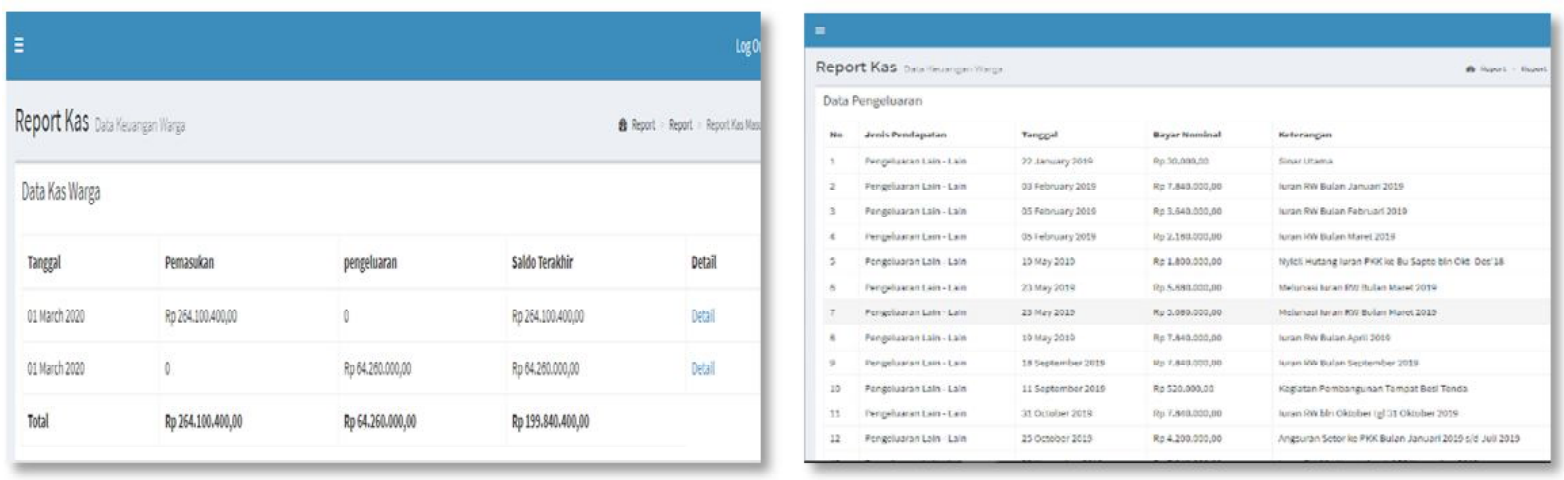

Gambar 11. Report Pengeluaran Kas

Gambar 12. Report Kas

Membuat Report Kas RT. Total pemasukan dan pengeluaran kas setiap bulan berjalan beserta saldonya tercantum pada fitur ini, sehingga fungsinya adalah memonitor saldo pemasukan maupun pengeluaran kas secara khusus bagi pengurus RT maupun warga. Laporan pemasukan dan pengeluaran yang masing-masing terpisah seperti pada Gambar 10 dan 11 akan termonitor jumlah keseluruhannya pada menu report kas RT seperti yang tercantum pada Gambar 12 perihal Report Kas

Melakukan sosialisasi. Hasil dari integrasi fitur pembayaran iuran dan laporannya pada aplikasi SiWarga GPA adalah sosialisai pembayaran iuran dan monitoring aplikasi SiWarga yang dilakukan secara daring seperti tercantum pada Gambar 13. Beberapa pencapaian dari sosialisasi tersebut adalah: (1) Pengurus RT telah 100\% mengunduh dan menggunakan aplikasi SiWarga pada gadget masing-masing. (2) Segenap pengurus RT telah berhasil mengaplikasikan proses administrasi setup iuran dan generate laporan keuangan RT pada Siwarga GPA. (4) Aplikasi SiWarga yang berbasis android telah terinstall pada gadget masing-masing warga dengan mengikuti panduan aplikasi yang tercantum pada media sosial youtube. (4) Tingkat persentase warta yang telah melaporkan pembayaran iuran melalui aplikasi SiWarga GPA pada awal Juli 2020 sebesar 70\%, sedangkan sisanya masih secara manual yaitu dengan cara melaporkan pembayaran dan mengirimkan bukti transfer kepada pengurus RT.
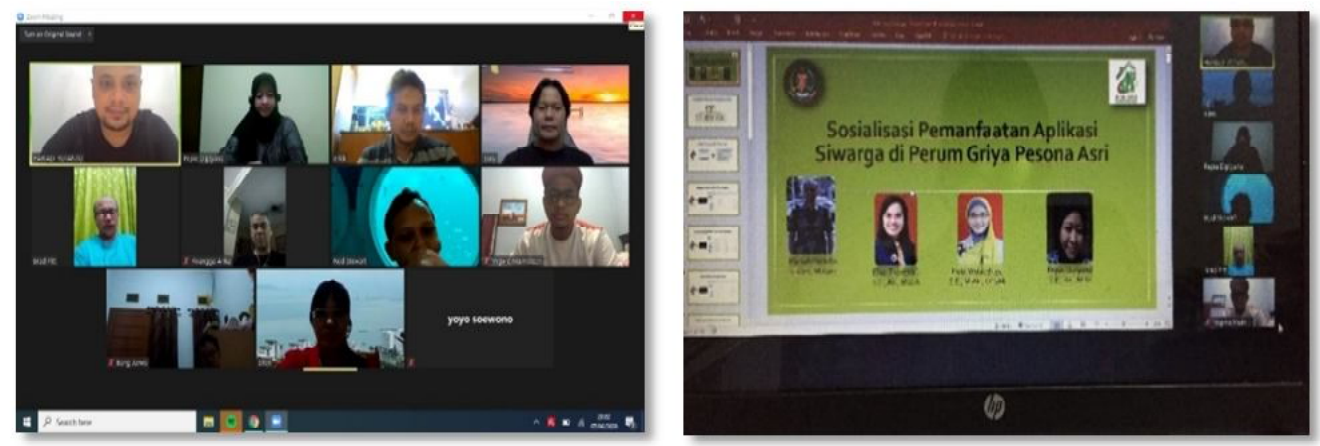

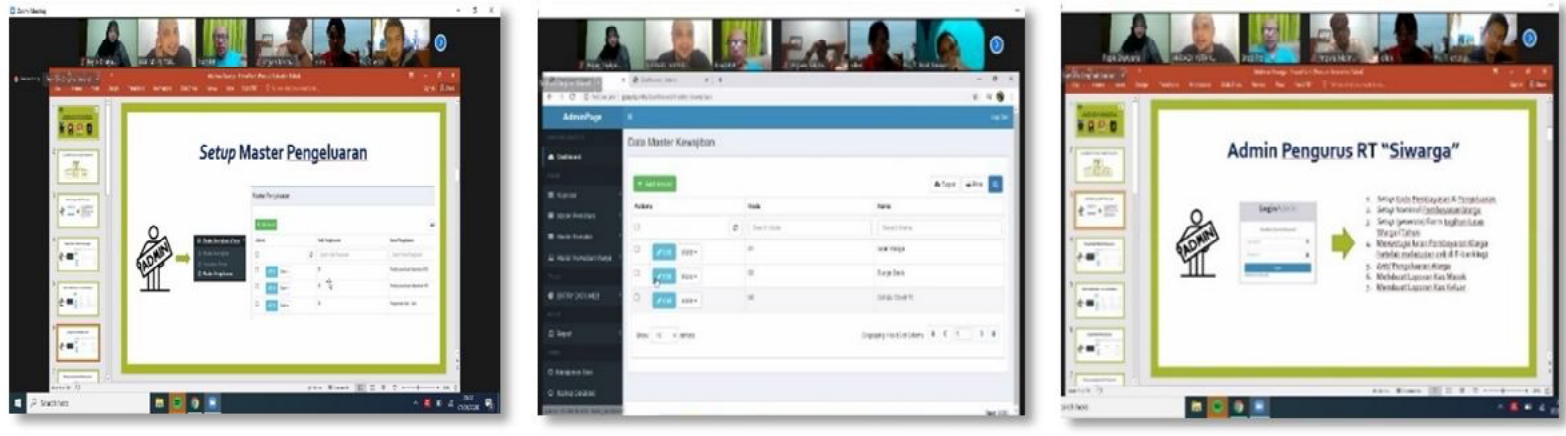

Gambar 13. Sosialisasi Aplikasi SiWarga secara Daring

\section{SIMPULAN DAN SARAN}

\section{Simpulan}

Kesimpulan dari hasil kegiatan program kemitraan masyarakat ini adalah sejumlah pengurus RT telah menguasai penggunaan beberapa fitur SiWarga yang telah dikembangkan. Sejumlah warga juga sudah mulai tertib membayar iuran. Namun, masih ada keterlambatan pembayaran iuran sekitar 30\%, karena masih membayar secara manual berdasarkan kondisi pada awal Juli 2020. Sejumlah pengurus dan waga sudah cukup mahir menggunakan aplikasi SiWarga sebelumnya aplikasi tersebut telah digunakan juga untuk administrasi warga setempat bahkan telah digunakan untuk e-voting. Selain itu sejumlah pengurus dan warga juga cukup antusias menggunakan aplikasi tersebut karena memberikan kemudahan bagi warga maupun bagi pengurus. Warga dapat memonitoring sejumlah tunggakan pembayarannya demikian juga pengurus RT dapat memonitoring sejumlah warga yang sudah maupun belum membayar iuran, tanpa harus menagih dari satu rumah ke rumah warga lainnya. Pengurus RT juga dapat mengetahui secara total besar pemasukan maupun pengeluaran kas RT sehingga dapat digunakan untuk anggaran perancangan pengeluaran kas. Hal yang terpenting lagi terkait dengan masa pandemi saat ini, melalui aplikasi ini sejumlah warga perumahan Griya Pesona Asri juga secara tidak langsung telah menerapkan social distancing sebagai salah satu bentuk pencegahan penyebaran COVID-19.

\section{Saran}

Berdasarkan hasil dari pengembangan aplikasi SiWarga berkaitan dengan fitur pembayaran iuran dan monitoringnya, maka beberapa saran adalah sebagai berikut.

Pendampingan berkelanjutan secara berkala. Kegiatan ini sebaiknya dilaksanakan secara berkelanjutan agar warga Perumahan Griya Pesona Asri tetap konsisten dengan penggunaan aplikasi SiWarga dan manfaatnya dapat terus berkelanjutan. Selain itu dari pendampingan berkelanjutan dapat diketahui kebutuhan dan keinginan warga terhadap pengembangan fitur aplikasi SiWarga.

Kerjasama dengan pihak ketiga. Aplikasi SiWarga dapat dikembangkan kembali dengan melibatkan pihak ketiga sehingga dapat digunakan juga sebagai alat pembayaran non tunai dengan mendapatkan keuntungan seperti cash back. Terutama untuk pembayaran iuran dapat dilakukan melalui aplikasi teknologi keuangan atau yang dikenal dengan istilah fintech seperti aplikasi OVO, DANA, Link dan sebagainya. 
Pengembangan sistem keamanan SiWarga. Antusias warga terhadap penggunaan aplikasi SiWarga perlu mendapatkan apresiasi dengan peningkatan keamanan, terutama apabila sudah dapat bekerjasama dengan pihak ketiga. Secara khusus yang berkaitan dengan data nasabah dan keuangannya sehingga tingkat kepercayaan warga juga semakin meningkat terhadap penggunaan teknologi tersebut.

\section{UCAPAN TERIMA KASIH}

Ucapan terima kasih disampaikan kepada Pusat Penelitian dan Pengabdian Masyarakat STIE Perbanas Surabaya atas sejumlah bantuan dana selama pelaksanaan kegiatan Program Kemitraan Masyarakat. Ucapan terima kasih juga disampaikan oleh tim pengabdian masyakarat kepada segenap pengurus Perum Griya Asri RT 04, RW 10 Medokan Ayu Surabaya.

\section{DAFTAR PUSTAKA}

Asana, I. M. D. P., Putra, P. S. U., \& Atmajaya, K. J. (2020). Penerapan sistem informasi data iuran di sekretariat Warga Tutuan Gunaksa. Jurnal Anadara Pengabdian Kepada Masyarakat, 2(1), 12-17.

Christanto, F. W., Handayani, S., \& Utomo, V. G. (2019). Pemanfaatan sistem informasi kematian warga berbasis website di Kelurahan Beji Kabupaten Semarang. Jurnal Pengabdian Kepada Masyarakat, 9(1), 77-82. https://doi.org/10.30999/jpkm.v9i1.600

Davis, F. D. (1989). Perceived usefulness, perceived ease of use, and user acceptance of information technology. MIS Quarterly, 13(3), 319-340. https://doi.org/10.2307/249008

Gasova, K., \& Stofkova, K. (2017). E-Government as a Quality Improvement Tool for Citizens' Services. In Procedia Engineering, 192, 225-230 https://doi.org/10.1016/j.proeng.2017.06.039

Kustriyanti, S., Windana, F., \& Shofiya, A. (2018). Penerapan Sistem informasi pembayaran iuran berbasis komputer pada pusat kegiatan belajar masyarakat Zamzam. JAST: Jurnal Aplikasi Sains Dan Teknologi, 2(2), 35- . https://doi.org/10.33366/jast.v2i2.1044

Lintangsari, N. N., Hidayati, N., Purnamasari, Y., Carolina, H., \& Ramadhan, W. F. (2018). Analisis pengaruh instrumen pembayaran non-tunai terhadap stabilitas sistem keuangan di Indonesia. Jurnal Dinamika Ekonomi Pembangunan, 1(1), 47-62. https://doi.org/10.14710/jdep.1.1.47-62

Peraturan Bank Indonesia No.19//PBI/2017. Gerbang Pembayaran Gateway. No.18/17/PBI/2016. Uang Elektronik

Peraturan Presiden No 82/PerPres/2016. Strategi Nasional Keuangan Inklusif

Welch, E. W., Hinnant, C. C., \& Moon, M. J. (2005). Linking citizen satisfaction with e-government and trust in government. Journal of Public Administration Research and Theory, 15(3), 371-391. https://doi.org/10.1093/jopart/mui021

Yutanto, H., Ilham, R., Salma, K. R., \& Effendi, Y. (2019). Pengembangan sistem informasi pada local egovervenance untuk peningkatan kinerja pelayanan warga. Jurnal Sistem Informasi Bisnis, 9(2), 220-227. https://doi.org/10.21456/vol9iss2pp220-227 
